\title{
Foraging behaviour of bank cormorants in Namibia: implications for conservation
}

\author{
Katrin Ludynia ${ }^{1,2, *}$, Rian Jones ${ }^{4}$, Jessica Kemper ${ }^{4}$, Stefan Garthe ${ }^{3}$, \\ Les G. Underhill ${ }^{1,2}$ \\ ${ }^{1}$ Animal Demography Unit, Department of Zoology, University of Cape Town, Rondebosch 7701, Cape Town, South Africa \\ ${ }^{2}$ Marine Research Institute, University of Cape Town, Rondebosch 7701, Cape Town, South Africa \\ ${ }^{3}$ Research and Technology Center Westcoast, University of Kiel, Hafentoern 1, 25761 Buesum, Germany \\ ${ }^{4}$ Ministry of Fisheries and Marine Resources, Lüderitz Marine Research, PO Box 394, Lüderitz, Namibia
}

\begin{abstract}
We studied the foraging and diving behaviour of male bank cormorants Phalacrocorax neglectus at Mercury Island, Namibia, during the 2007-2008 breeding season. The island hosts the world's largest breeding colony of this endangered species. Population numbers are currently stable at Mercury Island, whereas numbers at other colonies in Namibia are decreasing, including those at formerly important colonies. This trend is presumably due to reduced food availability. At Mercury Island, bank cormorants foraged inshore (ca. $2 \mathrm{~km}$ off the coast) in close vicinity to their breeding site (ca. $3 \mathrm{~km}$ off the colony) and dived to an average depth of $30 \mathrm{~m}$. Diet at Mercury Island was dominated by demersally occurring pelagic goby Sufflogobius bibarbatus. Our findings suggest that bank cormorants are benthic feeders along their entire range and that their foraging behaviour in Namibia does not differ from that suspected in South Africa. Further studies, extending to other breeding sites, are needed to explain the different population trends and how these may be influenced by food availability. The identification of important foraging sites will play a crucial role in the management of Namibia's first Marine Protected Area and will contribute towards the protection of this species.
\end{abstract}

KEY WORDS: Bank cormorant $\cdot$ Phalacrocorax neglectus $\cdot$ Namibia $\cdot$ Foraging $\cdot$ Benthic diving · Endangered species

\section{INTRODUCTION}

Bank cormorants Phalacrocorax neglectus are endemic to the Benguela Upwelling System and are listed as endangered (Kemper et al. 2007, IUCN 2008). Mercury and Ichaboe Islands in Namibia, near the northern extreme of the species' range (Fig. 1), support 70 to $80 \%$ of the species (Kemper et al. 2007), while other breeding localities in Namibia and South Africa hold the remainder in smaller colonies (Kemper et al. 2007, Crawford et al. 2008a; Fig. 1). Since the 1990s, numbers in South Africa have shown a slight overall decrease (Crawford et al. 1999) but an increase at some colonies since 2000 (Crawford et al. 2008a), whereas bank cormorants breeding in Namibia declined by 68\% between 1993 and 1998 (Roux \& Kemper 2009). Numbers at Ichaboe Island, previously the world's largest breeding colony, have not recovered and the Namibian population continues to decrease (Kemper et al. 2007). The main reason for the overall population decline is thought to be food shortage (Crawford et al. 1999, 2008a), but other factors, e.g. predation and displacement by seals, also play an important role (Crawford et al. 1989, du Toit et al. 2004).

Since 1999, Mercury Island has hosted the world's largest breeding colony with ca. 1840 breeding pairs during peak breeding (Kemper et al. 2007). At Mercury Island, numbers have increased since the late 1990s and have been stable since 2004. Namibia's first 


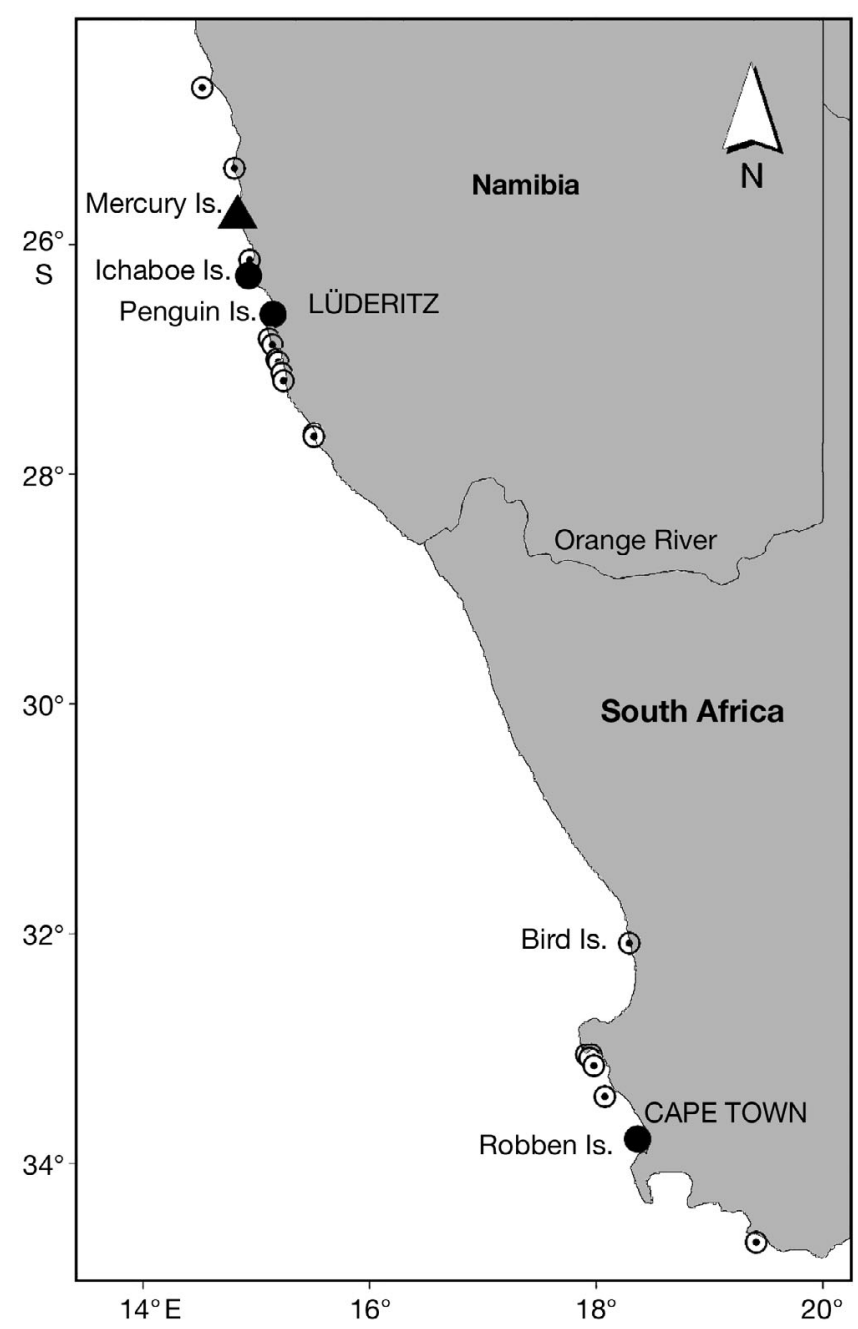

Fig. 1. Phalacrocorax neglectus. Breeding sites of bank cormorants along the Namibian and South African coast. $\odot$ : colonies with $<100$ breeding pairs; : colonies with 100 to 300 breeding pairs; $\boldsymbol{\Delta}$ : indicates Mercury Island with $>1800$ breeding pairs (data from Kemper et al. 2007)

Marine Protected Area, the Namibian Islands' Marine Protected Area (NIMPA), was proclaimed in 2009 (Government Gazette notice no. 4210 of 16 February 2009) and encompasses all breeding sites for bank cormorants in Namibia. Its chief aim is the protection of a number of threatened species, as well as key breeding and foraging habitats along Namibia's southern coast. The identification of foraging areas of bank cormorants and other threatened bird species in the NIMPA is essential for the successful implementation of management plans and, ultimately, the conservation of this species.

Few studies have investigated the foraging and diving behaviour of bank cormorants (Siegfried et al. 1975, Cooper 1985b, Wilson \& Wilson 1988); these used different methods, making comparisons difficult. A better understanding of bank cormorant foraging ecology, especially regarding differences between breeding localities, is crucial for their protection. Timing of breeding (Crawford et al. 1999) and colony sizes (Crawford et al. 1999, Kemper et al. 2007) vary across bank cormorants' breeding range and differences are also assumed to exist in their foraging and diving behaviour (Crawford et al. 1985, Hockey et al. 2005). Bank cormorants have been observed feeding inshore and in close vicinity to their breeding sites (Siegfried et al. 1975, Cooper 1985b). Bank cormorants in South Africa feed mainly on Cape rock lobster Jasus lalandii, thus feeding at the sea bottom, while the main prey for this species breeding in Namibia is pelagic goby Sufflogobius bibarbatus (Cruickshank et al. 1980, Cooper 1985b, Crawford et al. 1985, 2008a). This has led to the assumption that bank cormorants feed pelagically, in the water column, in Namibian waters (Crawford et al. 1985, Hockey et al. 2005).

The present study investigated the diving and foraging behaviour and foraging areas of breeding bank cormorants at Mercury Island, Namibia, using data logger technology and nest observation data. We examined whether bank cormorants in Namibia are actually pelagic feeders in contrast to their conspecifics in South Africa (Crawford et al. 1985), identified important foraging areas and offer potential reasons for the positive population trends at Mercury Island.

\section{MATERIALS AND METHODS}

Study site. The study was carried out at Mercury Island, Namibia $\left(25^{\circ} 43^{\prime} \mathrm{S}, 14^{\circ} 50^{\prime} \mathrm{E}\right.$; Fig. 1), during the 2007-2008 breeding season. Nest observations and data logger deployment took place between 14 February and 6 March 2008.

Nest observations. Nest observations were carried out from vantage points at different breeding colonies around the island. Between 5 and 13 nests were observed at the same time, recording departure and arrival times of individual birds. We did not determine the sex of the birds but nest status was noted (nests with eggs or chicks or birds building the nest). Observation periods lasted between 01:15 and 03:45 $h$; incomplete trips (i.e. birds not observed departing or returning) were excluded. We distinguished trips made for the purpose of foraging or the collection of nest material by trip duration. Birds observed returning with nest material usually did not spend more than 10 min away from the nest site (see 'Results'); we therefore defined foraging trips as those longer than $10 \mathrm{~min}$. Daylight periods were defined as 06:30 to $20: 00 \mathrm{~h}$. 
Data logger deployment. We used a geographical positioning system MiniGPS (earth\&OCEAN Technologies) weighing $29 \mathrm{~g}$ with dimensions of $46.5 \times 32 \times$ $18.5 \mathrm{~mm}$ (length $\times$ width $\times$ height). MiniGPS were set to record positional information every minute; accuracy in this mode is ca. $10 \mathrm{~m}(65 \%$ of all fixes with accuracy of $<10 \mathrm{~m}$ in intermittent mode; earth\& OCEAN Technologies pers. comm.). The second data logger type used was the temperature-depth recorder PreciTD (earth\&OCEAN Technologies), weighing $23 \mathrm{~g}$ and with a diameter of $19 \mathrm{~mm}$ and a length of $80 \mathrm{~mm}$. These devices were set to measure pressure (i.e. water depth) and temperature every second; in most cases memory size (2 MB) allowed for data storage of the entire deployment period. Devices were attached to the center tail feathers using Tesa ${ }^{\circledR}$ tape, placed either on top or underneath the tail (MiniGPS and PreciTD, respectively). Devices used in the present study weighed less than $1.5 \%$ of the bird's body mass and only one device was used on each individual.

Devices were deployed on 17 breeding bank cormorants. Birds were raising 1 to 3 chicks of different ages (few days to several weeks of age) and only one partner of each nest was handled. We used MiniGPS data loggers on 7 and PreciTD data loggers on 10 birds. We sexed the birds according to body size, males being the larger member of the pair (Cooper 1985a). Devices were deployed on 15 males (average \pm SD mass $=2.04$ $\pm 0.18 \mathrm{~kg}$ ) and 2 females (both weighing $1.74 \mathrm{~kg}$ ).

Birds were captured at their nest sites using a hooked pole. Weighing and logger deployment took less than $8 \mathrm{~min}$, after which the birds were returned to their nests. Data loggers were removed after 1 to $3 \mathrm{~d}$, except in one case where a female (carrying a MiniGPS device) did not return and abandoned her nest. After the departure of the partner $2 \mathrm{~d}$ later, the chicks were transferred to another nest where they were successfully raised to fledging.

Data analysis. We present data for 13 males successfully equipped with data loggers (1 MiniGPS and 1 PreciTD did not yield data); the data from the 1 female carrying a PreciTD device are only used for comparison. Data were obtained from 8 male birds equipped with PreciTD loggers. For 1 bird no pressure data were recorded, so dive data for 7 birds are presented. The number of dives for the eighth bird was determined using the temperature signal. Trip duration data were available for all 13 birds. An ANOVA was used to compare trip durations for different device types and chick-rearing birds observed in the colony using the open source software package R 2.4.1 (www. r-project.org).

Positional data obtained from MiniGPS devices were plotted and analysed using ArcView 3.2 (ESRI). Only trips with more than one position obtained away from the colony were included. When only one fix was recorded away from the colony, this was not considered a trip but rather inaccurate positioning. Adaptive kernel analysis using ArcView 3.2 was used to calculate the overlap of foraging areas between individual birds, based on the $50 \%$ kernel volume contour (De Solla et al. 1999, Wood et al. 2000).

Consecutive positions that showed that the bird had travelled $<50 \mathrm{~m} \mathrm{~min}^{-1}$ were defined as foraging areas. This value was chosen according to the frequency distribution of distance travelled between fixes, of which $50 \%$ were $<50 \mathrm{~m} \mathrm{~min}^{-1}$. The activity recorded using PreciTDs (see 'Results: Diving') underlines this definition.

Temperature and pressure signals of birds equipped with PreciTD data loggers were used to estimate trip durations and at-sea activities, such as surface periods, flying and diving, using the methods devised by Wilson et al. (1995) and Garthe et al. (1999). High and relatively stable temperatures indicated the birds' presence in the colony, while departures to sea were characterized by a sudden change in the temperature signal which fluctuated until the bird landed on the water. Surface periods showed a stable and relatively low temperature signal and water temperatures were confirmed by measurements at the island. Dives were defined by the pressure signal as well as by a drop in temperature (used as a proxy for the device with the
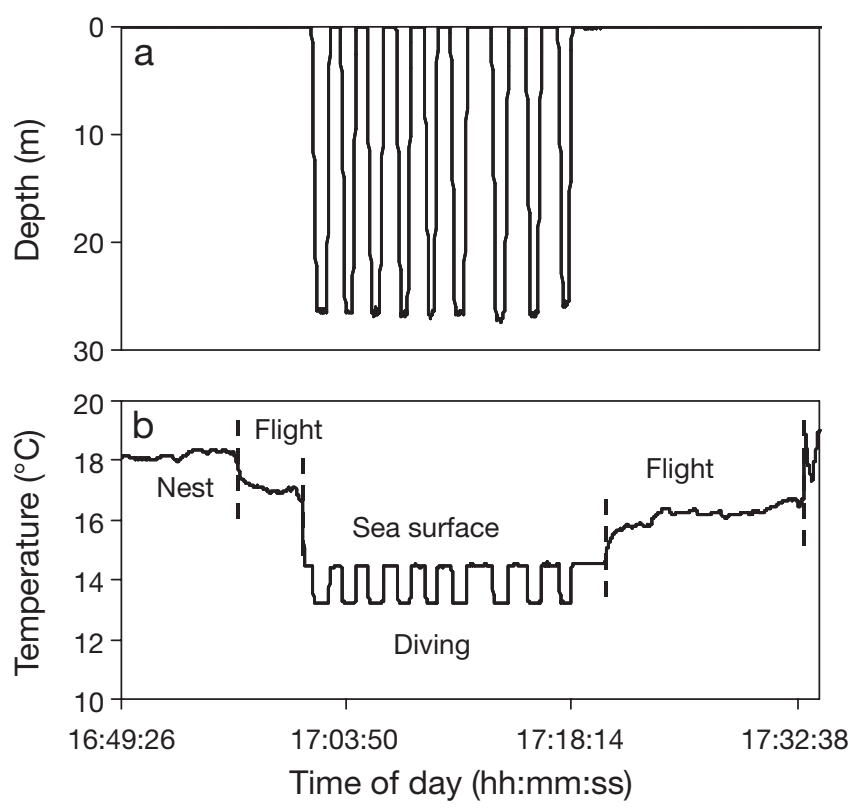

Fig. 2. Phalacrocorax neglectus. Example of the (a) depth and (b) temperature signal recorded during a single foraging trip using PreciTD data loggers. Different activities identified by the temperature signal are pointed out in (b); sea surface refers to the time the bird spent at the sea surface between and after dives 
malfunctioning pressure signali Fig. 2). Post-dive intervals (PDI) were defined as the surface time following each dive which ended when the bird either dived again or was presumed flying (see Tremblay et al. 2005). Dives were defined as being $>1 \mathrm{~m}$ depth and a sequence of dives not interrupted by flying was defined as a dive bout. Bottom time was defined as the period of a dive when the vertical velocity of the bird was $<0.2 \mathrm{~m} \mathrm{~s}^{-1}$ after linear descent and before linear ascent phases. Dive sequences in which successive maximum dive depths were within $10 \%$ of each other were analysed for potential bottom feeding (following Tremblay \& Cherel 2000). Time spent underwater was calculated as the sum of all dive durations per trip. Correlations between trip duration, time spent at the surface, time spent under water, number of dives and flight time were tested using a linear model in R 2.4.1. One trip with an untypically long surface period after the last dive ( $>1 \mathrm{~h}$ ) was excluded from the correlation analysis. Individual differences in dive duration and dive depth were tested using a permutation test as per Oatley \& Underhill (2001).

To determine possible foraging areas of birds equipped with PreciTD devices (thus not yielding any information about their locations at sea), distances were calculated by multiplying the average flight speed calculated from MiniGPS devices during periods of commuting, equalling $50 \mathrm{~km} \mathrm{~h}^{-1}\left(13.8 \mathrm{~m} \mathrm{~s}^{-1}\right)$, with flight times between departure from the nest and the first activity at sea (floating or diving) and between the last activity and the return to the nest. Possible locations of these foraging areas and the corresponding dive depths were then compared to bathymetric data (South African Navy Chart SAN 110) to evaluate bottom diving.

\section{RESULTS}

\section{Foraging trip length}

In $92.2 \%$ of all trips observed ( $\mathrm{n}=86$ ), birds returning with nest material stayed away for $<10 \mathrm{~min}$. We therefore defined trips $>10$ min in duration as foraging trips. Foraging trips of chick-rearing birds observed in the colony had a mean $( \pm \mathrm{SD})$ duration of $41.4 \pm$ $19.8 \min (\mathrm{n}=46$, range $=12$ to $115 \mathrm{~min}$; Table 1$)$. Mean trip durations did not differ significantly between different data logger types nor between data logger and observation-derived data $\left(\right.$ ANOVA, $F_{2,157}=1.465, \mathrm{p}=$ 0.234 ; Table 1). The mean foraging trip duration for all trips combined was $39.3 \pm 17.4 \mathrm{~min}(\mathrm{n}=144$ trips $)$.

Birds deployed with data loggers averaged 4 trips per day (mean $\pm \mathrm{SD}=3.8 \pm 1.4$; considering only days with complete data logger coverage). Birds made a
Table 1. Phalacrocorax neglectus. Trip durations of foraging trips (>10 min) of chick-rearing bank cormorants at Mercury Island, Namibia, in February and March 2008. Birds equipped with PreciTD and MiniGPS data loggers included only male birds; sexes of birds observed in the colony are unknown. Duration values were obtained from nest observations for undeployed birds and from recorded trip durations for birds deployed with data loggers

\begin{tabular}{|lccc|}
\hline Data source & No. of trips & $\begin{array}{c}\text { Trip duration } \\
\text { Mean } \pm \mathrm{SD}\end{array}$ & Range \\
\hline & \multicolumn{4}{c|}{$41.4 \pm 19.8$} & $12-115$ \\
Observations & 46 & $49.7 \pm 17.8$ & $17-120$ \\
PreciTD ( $\mathrm{n}=8$ birds) & 64 & $35.5 \pm 12.3$ & $13-62$ \\
MiniGPS ( $\mathrm{n}=5$ birds) & 34 & 35 \\
\hline
\end{tabular}

maximum of 7 trips for nest material in one day. Total time at sea per day averaged $131 \pm 45 \mathrm{~min}(\mathrm{n}=16 \mathrm{com}-$ plete days of 11 birds, range $=68$ to $228 \mathrm{~min}$ ), thus only $16.2 \%$ of the daylight period was used for foraging. The average time between consecutive foraging trips (ignoring short trips for nesting material) was $144 \pm$ $73 \min (\mathrm{n}=64$, range $=3$ to $344 \mathrm{~min})$. The earliest trip in the morning started $14 \mathrm{~min}$ after local sunrise at 06:44 $\mathrm{h}$ and the latest return of a bird to the colony took place at 19:34 h, 26 min before local sunset. No activity was recorded during the night.

The mean $( \pm \mathrm{SD})$ trip duration of 15 trips made by the single female was $44.7 \pm 16.7 \mathrm{~min}$. This bird spent 209 and $269 \mathrm{~min}$ ( 25.8 and $33.2 \%$ of the daylight period) at sea on 2 consecutive days. Foraging took place between 06:57 and 18:21 h.

\section{Foraging areas}

The 5 birds successfully equipped with MiniGPS data loggers flew in a southwesterly direction to forage (Fig. 3). Three of the birds additionally flew in a northerly and northwesterly direction. Kernel analysis identified areas southwest of the island as well as surrounding the island as being used extensively by all birds combined (Fig. 3f). Individual birds foraged within the same area during several consecutive trips (see Fig. 3); $48 \%$ of all trips were within $1 \mathrm{~km}$ of the previous ones. Foraging areas during 6 trips recorded for Bird 1 were not farther than $400 \mathrm{~m}$ apart (Fig. 3a). Kernel analysis further showed a large overlap of foraging areas between all birds: the $50 \%$ kernel volume contour of Birds 1 and 3 overlapped completely; the foraging area of Bird 9 fell within the $50 \%$ contour of all other birds; and Birds 9 and 12 used areas very similar to each other, both birds foraging in southerly and northerly directions from the island (Table 2, Fig. 3).

Mean $( \pm \mathrm{SD})$ maximum distances travelled from the colony were $3.2 \pm 2.2 \mathrm{~km} \mathrm{(n}=33$, range $=0.7$ to $8.6 \mathrm{~km}$; 

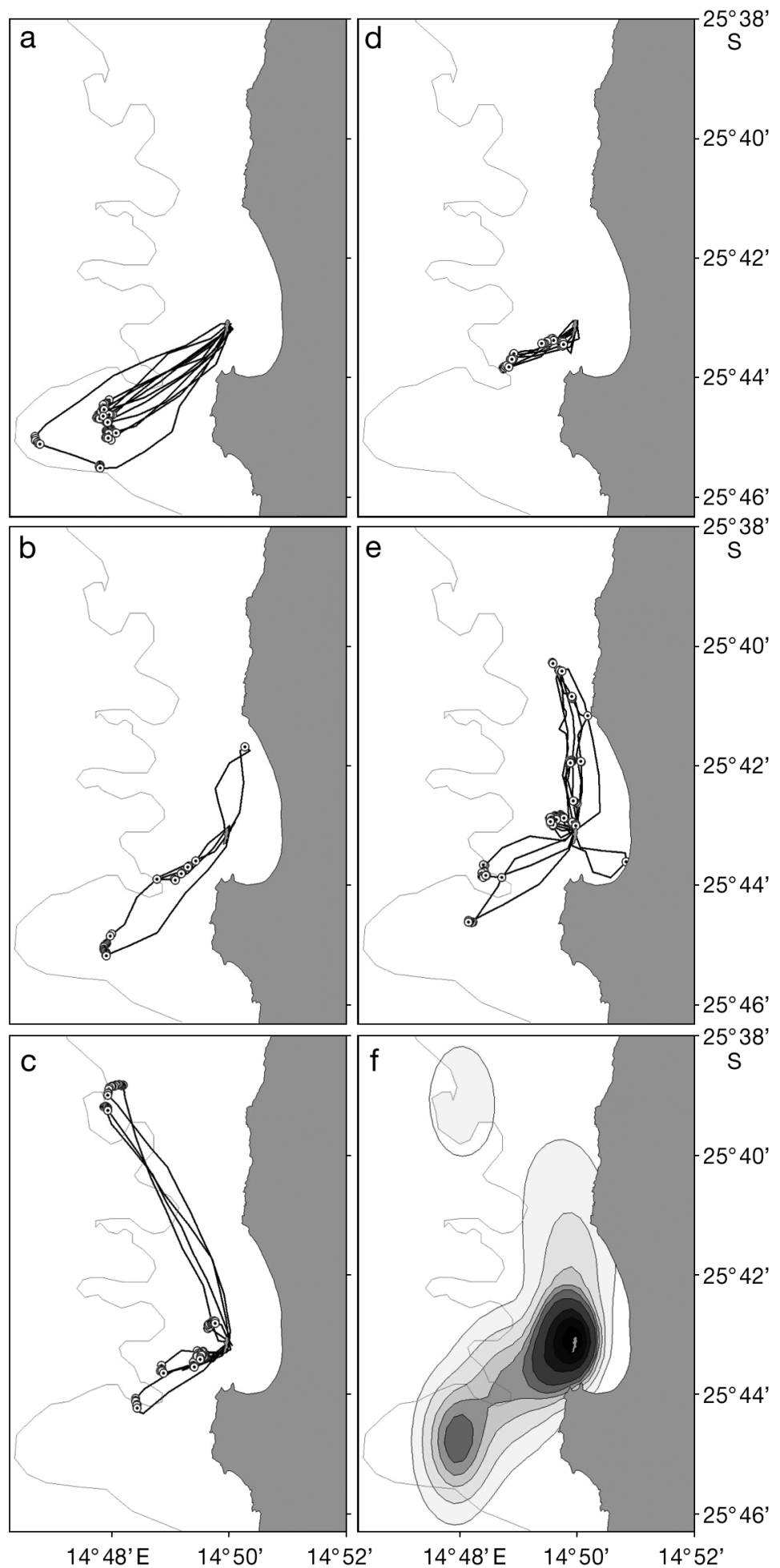

Fig. 3. Phalacrocorax neglectus. Foraging tracks and foraging positions $(\odot)$ of 5 male bank cormorants equipped with MiniGPS data loggers at Mercury Island, Namibia. Tracks shown in (a-e) are by birds no. 1, 3, 6, 9 and 12, respectively. Kernels shown in (f) are of all birds combined over a time period of $2 \mathrm{wk}$ in February and March 2008. Contours give the 10 to $90 \%$ kernel volumes, and the contour line in all panels represents the $50 \mathrm{~m}$ bathyline
Table 3) and birds travelled a mean distance of $7.8 \pm 5.0 \mathrm{~km}$ (range $=1.6$ to $19.8 \mathrm{~km}$ ) during foraging trips. Foraging areas (defined by time spent in a certain area, see 'Materials and methods') were located on average $3.1 \pm 2.3 \mathrm{~km}$ ( $\mathrm{n}=328$ foraging positions for 5 birds; range 0.2 to $8.6 \mathrm{~km}$ ) away from the colony and $2.1 \pm 0.4 \mathrm{~km}$ (range 0.1 to $5.0 \mathrm{~km}$ ) away from the mainland coast. All birds foraged in water $<50 \mathrm{~m}$ deep (Fig. 3). Foraging areas of birds carrying PreciTD devices (identified by flight time before and after dives) were located at an average distance of $2.6 \pm 1.6 \mathrm{~km}$ (range 0.2 to $10.4 \mathrm{~km}$ ) from the colony.

\section{Diving}

Seven male bank cormorants carrying PreciTD data loggers made 448 dives during 48 foraging trips. The mean $( \pm \mathrm{SD})$ number of dives per trip was $8.48 \pm 4.35$. Birds dived to a mean depth of $29.9 \pm 8.9 \mathrm{~m}$ (range $=1.7$ to $47.1 \mathrm{~m}$ ) and the mean duration was $72.4 \pm 12.8 \mathrm{~s}$ (range $=8$ to $115 \mathrm{~s}$; Table 4, Fig. $4)$. There were no significant differences in dive depth or dive duration between individuals (permutation test, $\mathrm{p}=0.157$ and $\mathrm{p}=$ 0.289 , respectively).

Birds dived to similar depths in consecutive dives (see Fig. 2a); the maximum depth of $98.4 \%$ of dives was within $10 \%$ of the maximum depth of the previous dive, suggesting that birds dived to the sea bottom at depths of ca. 30 and $40 \mathrm{~m}$. Shallow dives $(<10 \mathrm{~m})$ occurred near the beginnings and ends of foraging trips; $5.3 \%$ of all dives were shallow. Mean $( \pm \mathrm{SD})$ bottom time was $31.5 \pm 11.0 \mathrm{~s}$ (range $=0$ to $61 \mathrm{~s}$ ) and all dives with bottom times shorter than $10 \mathrm{~s}$ (3\% of all dives) were recorded at the beginning of a dive bout.

Birds floated on the water surface between dives (Fig. 2b); this behaviour made up $47.9 \pm 9.6 \%$ of the time at sea. PDI had a median duration of $68 \mathrm{~s}$ (range $=0$ to 1025 s). The maximum dive duration to PDI ratio $($ mean $=1.38$ ) was recorded for dives lasting between 40 and $50 \mathrm{~s}$, but ratio values of $>1.0$ were recorded for dives of up to $80 \mathrm{~s}$, thus for $72 \%$ of all dives (Fig. 4b). Less than $10 \%$ of all dives were followed by flight activity (mean duration $=80 \pm 107 \mathrm{~s}$ ). Flying was limited to commuting between breeding sites and foraging areas, and birds spent 
Table 2. Phalacrocorax neglectus. Percentage of area overlap of $50 \%$ kernel volume contour of foraging bank cormorants at Mercury Island, Namibia

\begin{tabular}{|c|c|c|c|c|c|}
\hline \multirow{2}{*}{ Bird no. } & & & \multirow{2}{*}{$\begin{array}{c}\text { Bird no. } \\
\quad 6\end{array}$} & \multirow[b]{2}{*}{9} & \multirow[b]{2}{*}{12} \\
\hline & 1 & 3 & & & \\
\hline 1 & - & 100 & 47.8 & 29.2 & 73.8 \\
\hline 3 & 100 & - & 64.8 & 31.9 & 71.7 \\
\hline 6 & 84.9 & 100 & - & 36.9 & 95.9 \\
\hline 9 & 100 & 100 & 100 & - & 100 \\
\hline 12 & 60.5 & 95 & 100 & 31.1 & - \\
\hline
\end{tabular}

$22.2 \pm 8.9 \%$ of their total time at sea flying. Trip duration was most strongly correlated with the time spent floating at the surface between and after dives $\left(\mathrm{r}^{2}=\right.$ $0.85, F_{1,62}=364.2, \mathrm{p}<0.001 ; \mathrm{n}=64$ trips of 8 birds), followed by the time spent underwater $\left(\mathrm{r}^{2}=0.56, F_{1,46}=\right.$ 59.5, $\mathrm{p}<0.001 ; \mathrm{n}=48$ trips of 7 birds) and the number of dives per trip $\left(\mathrm{r}^{2}=0.4, F_{1,62}=41.7, \mathrm{p}<0.001 ; \mathrm{n}=64\right.$ trips of 8 birds). Trip duration was also positively correlated with the time spent commuting between the colony and the foraging area, e.g. flying time $\left(\mathrm{r}^{2}=0.31\right.$, $F_{1,62}=27.97, \mathrm{p}<0.001 ; \mathrm{n}=64$ trips of 8 birds).

The only female from which we obtained data dived more frequently (mean $\pm \mathrm{SD}=13.3 \pm 8.4$ per trip) than male birds, but mean diving depth and dive duration were similar to those of male birds $(27.2 \pm$ $8.2 \mathrm{~m}$ and $64.3 \pm 14.8 \mathrm{~s}$ ). The maximum depth of $75 \%$ of dives was within the $10 \%$ of the previous maximum depth and the female cormorant dove to $<10 \mathrm{~m}$ in $13.5 \%$ of all dives. Additionally, the female flew for longer periods $(185 \pm 113 \mathrm{~s})$ between dive bouts. According to time spent flying before and after diving, the female bank cormorant foraged at an average distance of 2.5 $\pm 1.6 \mathrm{~km}$ (range $=0.7$ to $7.4 \mathrm{~km}$ ) from the colony.

\section{DISCUSSION}

Food availability is an important factor influencing seabird population sizes (e.g. Weimerskirch 2001). Poor food availability may directly affect breeding success (Aebischer 1986, Rindorf et al. 2000, Lewis et al. 2001, Wanless et al. 2005, 2007, Crawford et al. 2006), lead to emigration (Oro et al. 2004, Crawford et al. 2008b) and, under extreme circumstances, even cause adult mortality (Hays 1986, Duffy 1989, Boersma 1998). Food scarcity is suspected to pose a significant risk to a number of threatened seabird species in the Benguela system, including bank cormorants (Crawford et al. 1999, 2008a, Crawford 2007, Kemper et al. 2007). Studying the foraging behaviour of bank cormorants at Mercury Island might help to explain why it is the largest breeding colony and why its population is stable to increasing compared to other breeding sites. However, the lack of comparative data from other breeding sites on foraging behaviour and diet composition of bank cormorants makes answering these questions difficult.

Frequent trips of short duration and little time spent at sea indicate good prey availability close to the breeding colony (Cooper 1985b, Wanless et al. 1995,

Table 4. Phalacrocorax neglectus. Diving parameters for male bank cormorants at Mercury Island, Namibia, equipped with PreciTD data loggers in February and March 2008. Given are mean values $( \pm$ SD) for all trips $(n)$ during the time of logger recording (logger time) for each bird. nd: no data

\begin{tabular}{|lcccccc|}
\hline Bird no. $\mathrm{n}$ & $\begin{array}{c}\text { Logger time } \\
\text { (hh:mm:ss) }\end{array}$ & $\begin{array}{c}\text { Trip duration } \\
\text { (min) }\end{array}$ & \multicolumn{1}{c}{$\begin{array}{c}\text { Dives } \\
\text { trip }\end{array}$} & $\begin{array}{c}\text { Dive depth } \\
(\mathrm{m})\end{array}$ & $\begin{array}{c}\text { Dive } \\
\text { duration (s) }\end{array}$ \\
\hline 2 & 5 & $31: 27: 00$ & $54.2 \pm 8.4$ & $9.2 \pm 1.8$ & $39.3 \pm 2.2$ & $86.7 \pm 3.9$ \\
4 & 3 & $29: 57: 00$ & $54.3 \pm 5.1$ & $16.3 \pm 5.5$ & $25.7 \pm 0.6$ & $69.2 \pm 1.8$ \\
5 & 6 & $36: 53: 00$ & $41.8 \pm 15.7$ & $10.7 \pm 6.0$ & $26.8 \pm 2.6$ & $65.5 \pm 7.9$ \\
10 & 11 & $70: 51: 00$ & $26.7 \pm 8.4$ & $8.5 \pm 2.7$ & $23.7 \pm 7.1$ & $65.5 \pm 9.6$ \\
11 & 2 & $68: 12: 00$ & $41.5 \pm 7.8$ & $15.0 \pm 2.8$ & $22.8 \pm 2.7$ & $59.1 \pm 0.4$ \\
13 & 12 & $71: 59: 00$ & $33.0 \pm 13.8$ & $8.4 \pm 4.7$ & $33.8 \pm 9.0$ & $80.8 \pm 13.7$ \\
14 & 16 & $71: 48: 00$ & $25.4 \pm 7.5$ & $5.6 \pm 1.5$ & nd & nd \\
17 & 10 & $49: 23: 00$ & $41.5 \pm 28.2$ & $7.8 \pm 4.3$ & $32.4 \pm 11.0$ & $71.5 \pm 13.1$ \\
\hline
\end{tabular}

Table 3. Phalacrocorax neglectus. Foraging trip parameters of male bank cormorants at Mercury Island, Namibia, equipped with MiniGPS data loggers in February and March 2008. Given are mean values $( \pm$ SD) for all trips (n) during the time of logger recording (logger time) for each bird

\begin{tabular}{|lcccccc|}
\hline Bird no. & $\mathrm{n}$ & $\begin{array}{c}\text { Logger time } \\
(\mathrm{hh}: \mathrm{mm}: \mathrm{ss})\end{array}$ & $\begin{array}{c}\text { Trip duration } \\
(\mathrm{min})\end{array}$ & $\begin{array}{c}\text { Foraging } \\
\text { range }(\mathrm{km})\end{array}$ & $\begin{array}{c}\text { Distance } \\
\text { travelled }(\mathrm{km})\end{array}$ & $\begin{array}{c}\text { Distance to } \\
\text { Doraging positions } \\
\text { Distance to } \\
\text { coast }(\mathrm{km})\end{array}$ \\
\hline 1 & 6 & $27: 46: 00$ & $41.0 \pm 11.6$ & $5.1 \pm 0.8$ & $12.5 \pm 2.6$ & $4.3 \pm 0.6$ \\
3 & 3 & $29: 52: 00$ & $42.7 \pm 16.3$ & $3.5 \pm 1.5$ & $8.7 \pm 3.1$ & $3.2 \pm 0.6$ \\
6 & 8 & $53: 30: 00$ & $39.1 \pm 12.6$ & $3.3 \pm 3.2$ & $8.0 \pm 7.1$ & $3.4 \pm 3.3$ \\
9 & 5 & $25: 58: 00$ & $24.4 \pm 2.8$ & $1.8 \pm 0.7$ & $4.5 \pm 1.4$ & $2.2 \pm 1.2$ \\
12 & 11 & $71: 58: 00$ & $34.9 \pm 10.6$ & $2.7 \pm 1.9$ & $6.5 \pm 4.3$ & $2.3 \pm 1.5$ \\
\hline
\end{tabular}



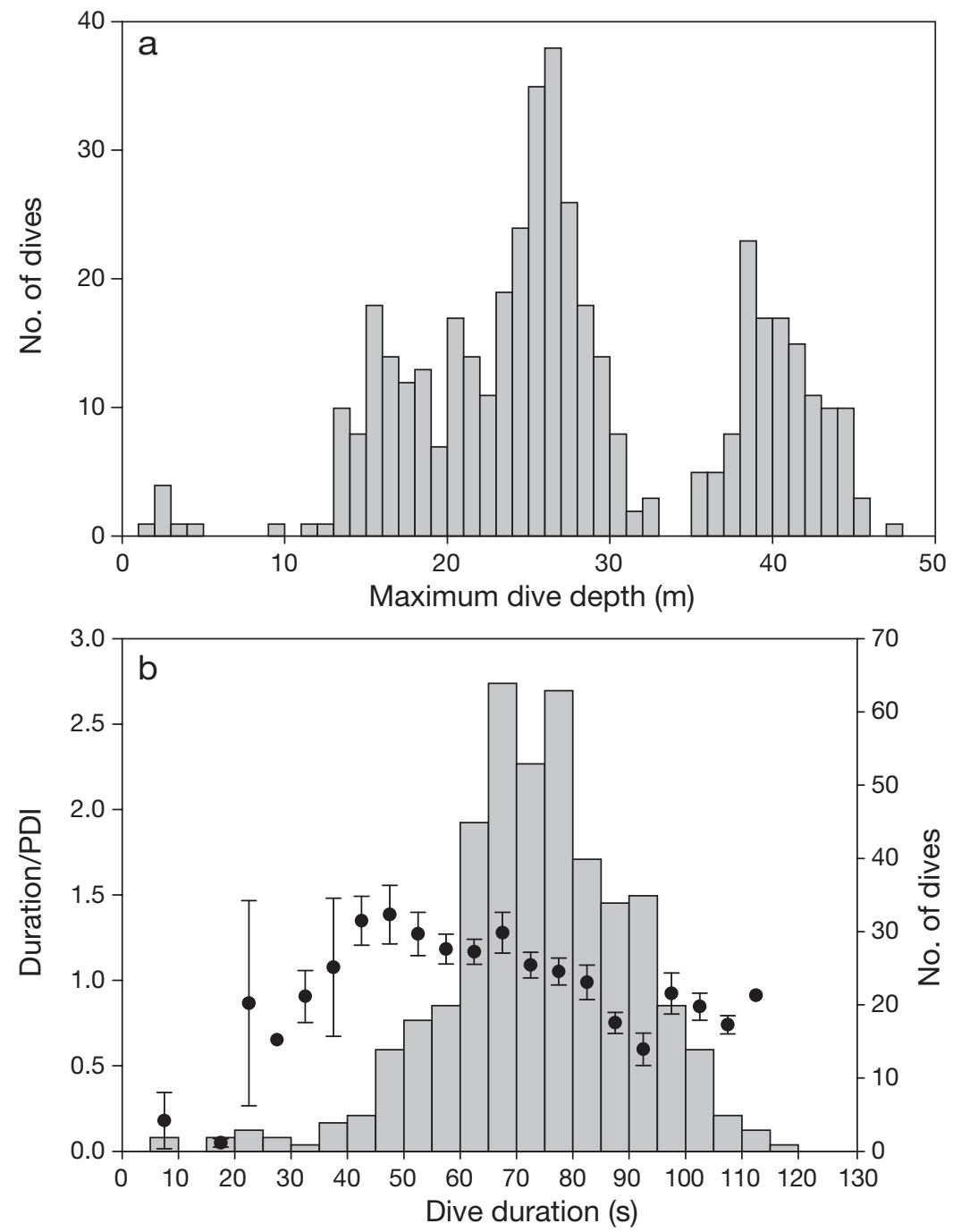

Fig. 4. Phalacrocorax neglectus. Frequency distribution of (a) maximum dive depth $(\mathrm{m})$ and $(\mathrm{b})$ dive duration to post-dive interval (PDI) ratio $\left(\bullet_{\text {; mean }} \pm \mathrm{SD}\right)$ and dive duration ( $\mathrm{s}$, bars) for male bank cormorants at Mercury Island, Namibia ( $\mathrm{n}=448$ dives)

Quintana 2001). Compared to foraging behaviour recorded for bank cormorants at Bird and Ichaboe Islands through direct observations (Cooper 1985b), male bank cormorants equipped with data loggers at Mercury Island undertook slightly more foraging trips per day (4 versus 3.5), with shorter trip lengths (38 versus $68 \mathrm{~min}$ ), and spent less time at sea per day (134 versus $240 \mathrm{~min}$ ). Trip duration in the present study was positively correlated with time spent at the surface between dives, number of dives and time spent underwater. Therefore, an increase in the time spent at sea was the result of increased foraging activity and only to a lesser extent due to increased flying time. Although we excluded trips shorter than 10 min from the analyses, some short trips, deemed to be nest material collection trips, included several deep dives (up to $29 \mathrm{~m}$ ).
We therefore may have underestimated the number of foraging trips. In addition, we may have introduced a bias in our results by only including male bank cormorants in the data logger analyses. Sex differences in foraging and diving behaviour, as well as colony attendance patterns, have been observed in several cormorant species (Bernstein \& Maxson 1984, Kato et al. 1992, 2000, Wanless et al. 1995, Watanuki et al. 1996, Cook et al. 2007), including bank cormorants (Cooper 1985b). Future studies might examine whether there are sex differences in foraging and breeding behaviour of bank cormorants and how these are related to size and weight differences between males and females.

Frere et al. (2008) defined foraging areas of cormorants by single positions where repeated dives were made at the same location. At Mercury Island, bank cormorants equipped with MiniGPS fed inshore and close to the colony, similar to the pattern observed at other breeding sites (Siegfried et al. 1975, Cooper 1985b). Flying was mostly restricted to commuting between the island and the foraging area and seldom occurred between dives. Individual birds showed strong foraging site fidelity, repeatedly visiting the same area southwest of the colony; individual birds returned to almost the exact spot in consecutive trips. This phenomenon has been reported for pelagic-feeding seabirds (e.g. gannets, Hamer et al. 2001; penguins, Watanuki et al. 2003; kittiwakes, Irons 1998) and benthic-feeding seabirds (e.g. penguins, Mattern et al. 2007; cormorants, Grémillet et al. 1999, Quintana 2001, Watanuki et al. 2004). Shags are suspected to memorize special characteristics of the environment and of the sea bottom topography in order to recognize efficient feeding areas in consecutive trips (Cook et al. 2006).

Bank cormorants at Mercury Island foraged almost exclusively at depths of ca. 30 and 40 m, which, taking into account the consistency of dive depth and bottom time duration in accordance with local bathymetry, indicates a benthic foraging behaviour (see Grémillet et al. 1998, 1999). Bottom-feeding has been documented for bank cormorants in South Africa feeding on rock lobster (Cooper 1985b, Williams 1987, Wilson \& Wilson 1988). Erroneously, bank cormorants in Namibia have been assumed to feed pelagically, owing to 
the high percentage of pelagic goby in their diet (Cruickshank et al. 1980, Cooper 1985b). Although juvenile pelagic goby are found in shoals in midwater, adult individuals occur in a more dispersed manner on the seafloor (Cruickshank et al. 1980, Melo \& Le Clus 2005). Grémillet et al. (1998) showed that individual cormorants may show flexible diving behaviour, thus being able to use both pelagic and benthic resources. Nevertheless, pellets of indigestible material regurgitated by bank cormorants at Mercury Island indicate that their diet is dominated by adult pelagic gobies of ca. 7 to $12 \mathrm{~cm}$ total length (Ministry of Fisheries and Marine Resources [MFMR], Namibia unpubl. data). Other prey species, such as sole (Soleidae), klipfish (Clinidae) and lobster, found in bank cormorant pellets at Mercury and Ichaboe Islands (MFMR unpubl. data) confirm our findings that bank cormorants in Namibia feed benthically. Although pellets may underrepresent certain prey types (Brown \& Ewins 1996), they are a useful tool for identifying the diet composition in cormorants (Duffy \& Laurenson 1983).

Our results indicate that bank cormorants may show benthic feeding behaviour throughout their range and that birds in Namibia are not necessarily pelagic feeders as previously stated by Crawford et al. (1985) and Hockey et al. (2005). Differences in prey composition may explain the longer dive durations observed in the present study compared to those reported from South Africa by Cooper (1985b) using observational data, which would rather overestimate dive duration. Bank cormorants in South Africa mainly feed on rock lobster (Crawford et al. 2008a). Birds preying on lobster presumably obtain only one prey item per dive, with which they often surface in order to shake off the legs (Avery 1983). Birds feeding on pelagic goby are able to catch and swallow several fish during a single dive, thus also reducing the risk of losing prey due to kleptoparasitism (Avery 1983). PDI were short and a high percentage of dive durations had a maximum dive duration to PDI ratio of $>1.0$. Longer surface times needed for handling lobsters would lead to an increase of PDI and less efficient foraging in terms of the percentage of time spent diving per foraging trip.

Pelagic goby is of relatively low energetic value (Cruickshank et al. 1980, K. Ludynia unpubl. data), but seems to be an abundant food source around Mercury Island, where it is also the dominant prey species in the diet of breeding African penguins (Crawford et al. 1985, Ludynia 2007, MFMR unpubl. data). Pelagic goby also seems to be a predictable food source as indicated by bank cormorants repeatedly foraging in the same area in the present study. Predictability of food sources may compensate for poor energy content (Grémillet et al. 2004). Bank cormorants at Ichaboe Island also feed predominantly on pelagic goby
(Cooper 1981, Crawford et al. 1985, Duffy et al. 1987, MFMR unpubl. data), but numbers of bank cormorants there have declined sharply since the early 1990s (MFMR unpubl. data). The causes for the different population trends are unclear, but are likely to be related to local predictability and abundance of prey. Numbers of breeding bank cormorants have decreased in areas with reduced abundance of rock lobster in South Africa (Crawford et al. 2008a), and most colonies in South Africa do not fall within the distribution of pelagic goby (Cruickshank et al. 1980). Studies on inter-island movement as well as breeding success of bank cormorants at Namibian and South African breeding sites are currently being undertaken (MFMR unpubl. data, R. Sherley unpubl. data). Further studies on the foraging ecology of bank cormorants are needed at all main breeding sites. The results of the present study, namely the identification of key foraging areas and diving behaviour for birds at Mercury Island, will be incorporated into the NIMPA's management plans. Possible management measures include a ban on lobster fisheries within the area to reduce risks of entanglement of benthic diving birds in traps (see Cooper 1985b), as well as measures to secure prey availability around breeding sites.

Acknowledgements. We are grateful to the MFMR for logistic support. Permission to work on bank cormorants was granted by MFMR. We are also thankful to J. James and K. Peard for help in the field and to G. Peters (earth\&Ocean technologies) for technical assistance. I. Wiesel helped with the kernel analysis. Many thanks to J.P. Roux for scientific support throughout the study and to T. Cook and R. Sherley for valuable input on the manuscript. We thank 3 anonymous reviewers for their comments. K.L. was financially supported by the German Academic Exchange Programme (DAAD) and by the Claude Leon Foundation.

\section{LITERATURE CITED}

Aebischer NJ (1986) Retrospective investigation of an ecological disaster in the shag, Phalacrocorax aristoteles: a general method based on long-term marking. J Anim Ecol 55: $613-629$

Avery G (1983) Bank cormorants Phalacrocorax neglectus taking Cape rock lobster Jasus lalandii. Cormorant 11: $45-48$

Bernstein NP, Maxson SJ (1984) Sexually distinct daily activity patterns of blue-eyed shags in Antarctica. Condor 86: 151-156

Boersma PD (1998) Population trends of the Galápagos penguin: impacts of El Niño and La Niña. Condor 100: 245-253

> Brown KM, Ewins J (1996) Technique-dependent biases in determination of diet composition: an example with ringbilled gulls. Condor 98:34-41

> Cook TR, Cherel Y, Tremblay Y (2006) Foraging tactics of chick-rearing Crozet shags: individual display repetitive activity and diving patterns over time. Polar Biol 29: $562-569$ 
Cook TR, Cherel Y, Bost CA, Tremblay Y (2007) Chick-rearing Crozet shags (Phalacrocorax melanogenis) display sex-specific foraging behaviour. Antarct Sci 19:55-63

Cooper J (1981) Biology of the bank cormorant, Part 1: distribution, population size, movements and conservation. Ostrich 52:208-215

Cooper J (1985a) Biology of the bank cormorant, Part 2: morphometrics, plumage, bare parts and moult. Ostrich 56: 79-85

Cooper J (1985b) Biology of the bank cormorant, Part 3: foraging behaviour. Ostrich 56:86-95

> Crawford RJM (2007) Food, fishing and seabirds in the Benguela upwelling system. J Ornithol 148:253-260

Crawford RJM, Cruickshank RA, Shelton PA, Kruger I (1985) Partitioning of a goby resource amongst four avian predators and evidence of altered trophic flow in the pelagic community of an intense, perennial upwelling system. S Afr J Mar Sci 3:215-228

Crawford RJM, David JHM, Williams AJ, Dyer BM (1989) Competition for space: recolonising seals displaced endangered, endemic seabirds off Namibia. Biol Conserv 48:59-72

> Crawford RJM, Dyer BM, Cordes I, Williams AJ (1999) Seasonal pattern of breeding, population trend and conservation status of bank cormorants Phalacrocorax neglectus off south western Africa. Biol Conserv 87:49-58

Crawford RJM, Barham PJ, Underhill LG, Shannon LJ and others (2006) The influence of food availability on breeding success of African penguins Spheniscus demersus at Robben Island, South Africa. Biol Conserv 132:119-125

Crawford RJM, Cockcroft AC, Dyer BM, Upfold L (2008a) Divergent trends in bank cormorants Phalacrocorax neglectus breeding in South Africa's Western Cape consistent with a distributional shift of rock lobster Jasus lalandii. Afr J Mar Sci 30:161-166

Crawford RJM, Sabarros PS, Fairweather T, Underhill LG, Wolfaardt AC (2008b) Implications for seabirds off South Africa of a long-term change in the distribution of sardine. Afr J Mar Sci 30:177-184

Cruickshank RA, Cooper J, Hampton I (1980) Extension to the geographical distribution of pelagic goby Sufflogobius bibartus off South West Africa and some mensural and energetic information. Fish Bull (S Afr) 13:77-82

De Solla SR, Bonduriansky R, Brooks RJ (1999) Eliminating autocorrelation reduces biological relevance of home range estimates. J Anim Ecol 68:221-234

du Toit M, Bartlett PA, Bester MN, Roux JP (2004) Seabird predation by individual seals at Ichaboe Island, Namibia. S Afr J Wildl Res 34:45-54

Duffy DC (1989) Seabirds and the 1982-84 El Niño/Southern Oscillation. In: Glynn PW (ed) Global ecological consequences of the 1982-83 El Niño-Southern Oscillation. Elsevier, Amsterdam, p 395-415

Duffy DC, Laurenson LJB (1983) Pellets of Cape cormorants as indicators of diet. Condor 85:305-307

Duffy DC, Wilson RP, Wilson MP (1987) Spatial and temporal patterns of diet in the Cape cormorant off southern Africa. Condor 89:830-834

Frere E, Quintana F, Gandini P, Wilson RP (2008) Foraging behaviour and habitat partitioning of two sympatric cormorants in Patagonia, Argentina. Ibis 150:558-564

> Garthe S, Grémillet D, Furness RW (1999) At-sea-activity and foraging efficiency in chick-rearing northern gannets Sula bassana: a case study in Shetland. Mar Ecol Prog Ser 185: 93-99

> Grémillet D, Argentin G, Schulte B, Culik BM (1998) Flexible foraging techniques in breeding cormorants Phalacroco- rax carbo and shags Phalacrocorax aristotelis: Benthic or pelagic feeding? Ibis 140:113-119

Grémillet D, Wilson RP, Storch S, Gary Y (1999) Three-dimensional space utilization by a marine predator. Mar Ecol Prog Ser 183:263-273

Grémillet D, Kuntz G, Delbart F, Mellet M and others (2004) Linking the foraging performance of a marine predator to local prey abundance. Funct Ecol 18:793-801

> Hamer KC, Phillips RA, Hill JK, Wanless S, Wood AG (2001) Contrasting foraging strategies of gannets Morus bassanus at two North Atlantic colonies: foraging trip duration and foraging area fidelity. Mar Ecol Prog Ser 224: $283-290$

- Hays C (1986) Effects of the 1982-1983 El Niño on Humboldt penguin colonies in Peru. Biol Conserv 36:169-180

Hockey PAR, Dean WRJ, Ryan PG (eds) (2005) Roberts birds of Southern Africa, VIIth edn. The Trustees of the John Voelcker Bird Book Fund, Cape Town

Irons DB (1998) Foraging area fidelity of individual seabirds in relation to tidal cycles and flock feeding. Ecology 79: 647-655

IUCN (2008) 2008 IUCN Red List of threatened species. Available at www.iucnredlist.org

Kato A, Croxall JP, Watanuki Y, Naito Y (1992) Diving patterns and performance in male and female blue-eyed cormorants Phalacrocorax atriceps at South Georgia. Mar Ornithol 19:117-129

Kato A, Watanuki Y, Nishiumi I, Kuroki M, Shaugnessy P, Naito Y (2000) Variation in foraging and parental behaviour of king cormorants. Auk 117:718-730

Kemper J, Underhill LG, Crawford RJM, Kirkman SP (2007) Revision of the conservation status of seabirds and seals breeding in the Benguela Ecosystem. In: Kirkman SP (ed) Final report of the BCLME (Benguela Current Large Marine Ecosystem) project on top predators as biological indicators of ecosystem change in the BCLME. Avian Demography Unit, Cape Town, p 325-342

> Lewis S, Wanless S, Wright PJ, Harris MP, Bull J, Elston DA (2001) Diet and breeding performance of black-legged kittiwakes Rissa tridactyla at a North Sea colony. Mar Ecol Prog Ser 221:277-284

Ludynia K (2007) Identification and characterisation of foraging areas of seabirds in upwelling systems. Biological and hydrographic implications for foraging at sea. $\mathrm{PhD}$ dissertation, University of Kiel

> Mattern T, Ellenberg U, Houston DM, Davis LS (2007) Consistent foraging routes and benthic foraging behaviour in yellow-eyed penguins. Mar Ecol Prog Ser 343: 295-306

Melo YC, Le Clus F (2005) Growth and reproduction of the pelagic goby Sufflogobius bibarbatus off the Orange River, southern Africa. Afr J Mar Sci 27:265-273

Oatley TB, Underhill LG (2001) Distances moved and elapsed times between ringing and recovery for three Ploceus weavers in southern Africa. Ostrich 72:41-44

Oro D, Cam E, Pradel R, Martínez-Abraín A (2004) Influence of food availability on demography and local population dynamics in a long-lived seabird. Proc R Soc Lond B 271: 387-396

Quintana F (2001) Foraging behaviour and feeding locations of rock shags Phalacrocorax magellanicus from a colony in Patagonia, Argentina. Ibis 143:547-553

Rindorf A, Wanless S, Harris MP (2000) Effects of changes in sandeel availability on the reproductive output of seabirds. Mar Ecol Prog Ser 202:241-252

Roux JP, Kemper J (2009) Bank cormorant. In: Simmons RE, Brown CJ (eds) Birds to watch in Namibia: red, rare and 
endemic species. National Biodiversity Programme \& Namibian Nature Foundation, Windhoek

Siegfried WR, Williams AJ, Frost PGH, Kinahan JB (1975) Plumage and ecology of cormorants. Zool Afr 10:183-192

Tremblay Y, Cherel Y (2000) Benthic and pelagic dives: a new foraging behaviour in rockhopper penguins. Mar Ecol Prog Ser 204:257-267

Tremblay Y, Cook TR, Cherel Y (2005) Time budget and diving behaviour of chick-rearing Crozet shags. Can J Zool 83:971-982

Wanless S, Harris MP, Morris JA (1995) Factors affecting daily activity budgets of South Georgian shags during chick rearing at Bird Island, South Georgia. Condor 97:550-558

Wanless S, Harris MP, Redman P, Speakman JR (2005) Low energy values of fish as a probable cause of a major seabird breeding failure in the North Sea. Mar Ecol Prog Ser 294:1-8

Wanless S, Frederiksen M, Daunt F, Scott BE, Harris MP (2007) Black-legged kittiwakes as indicators of environmental change in the North Sea: evidence from long-term studies. Prog Oceanogr 72:30-38

Watanuki Y, Kato A, Naito Y (1996) Diving performance of male and female Japanese cormorants. Can J Zool 74: 1098-1109

Editorial responsibility: Jonathan Green,

Liverpool, UK
Watanuki Y, Takahashi A, Sato K (2003) Feeding area specialization of chick-rearing Adélie penguins Pygoscelis adeliae in a fast-ice area. Ibis 145:558-564

> Watanuki Y, Ishikawa K, Takahashi A, Kato A (2004) Foraging behaviour of a generalist marine top predator, Japanese cormorants (Phalacrocorax filementosus), in years of demersal versus epipelagic prey. Mar Biol 145: $427-434$

Weimerskirch H (2001) Seabird demography and its relationship with the marine environment. In: Schreiber EA, Burger J (eds) Biology of marine birds. CRC Press, Boca Raton, FL, p 115-135

Williams AJ (1987) New seabird breeding localities, and an extension of the bank cormorant range, along the Namib coast of southern Africa. Cormorant 15:98-102

Wilson RP, Wilson MPT (1988) Foraging behaviour in four sympatric cormorants. J Anim Ecol 57:943-955

> Wilson RP, Weimerskirch H, Lys P (1995) A device for measuring seabird activity at sea. J Avian Biol 26:172-175

$>$ Wood AG, Naef-Daenzer B, Prince PA, Croxall JP (2000) Quantifying habitat use in satellite-tracked pelagic seabirds: application of kernel estimation to albatross locations. J Avian Biol 31:278-286

Submitted: November 23, 2009; Accepted: April 22, 2010 Proofs received from author(s): May 21, 2010 